\title{
BIOMASS PRODUCTION OF GIGANTIC GRASSES ARUNDO DONAX AND MISCANTHUS × GIGANTEUS IN THE DEPENDENCE ON PLANT MULTIPLICATION METHOD
}

\author{
MARCELA GUBIŠOVÁ*, JOZEF GUBIŠ, ALŽBETA ŽOFAJOVÁ
}

National Agricultural and Food Centre - Research Institute of Plant Production, Piešt'any, Slovak Republic

GUBIŠOVÁ, M. - GUBIŠ, J. - ŽOFAJOVÁ, A.: Biomass production of gigantic grasses Arundo donax and Miscanthus $\times$ giganteus in the dependence on plant multiplication method. Agriculture (Pol'nohospodárstvo), vol. 62, 2016, no. 2, p. $43-51$.

The effect of plant propagation method on growth parameters and the yield of above-ground biomass in two species of gigantic grasses were measured during three growing seasons. Plants were multiplied in explant culture and through traditional methods - by rhizome segments (Miscanthus $\times$ giganteus) or by stem cuttings (Arundo donax). In the case of $M$. × giganteus, in vitro-multiplied plants produced more shoots with significantly lower diameter, but the differences in the number of shoots, plant height and the yield of dry biomass were not statistically significant. Different results were observed for $A$. donax, where in vitro-multiplied plants showed significantly weaker results in all parameters, with the exception of the number of shoots in the first measured season. In both the species, there was observed the strong effect of the year. While in $M . \times$ giganteus the yield of dry biomass gradually decreased during the measured years, it increased in the case of giant reed.

Key words: energy plants, vegetative propagation, in vitro multiplication, rhizomes, stem cuttings

Increasing consumption of fossil fuel and the request for biofuels and bioenergy production has led to an increase in the importance of species with high biomass production. In the past decade, growers in Slovakia have shown interest in cultivation of biomass plants due to profitability from the crop. Miscanthus $\times$ giganteus and Arundo donax belong to the introduced species of family Poaceae, which cannot be overcome in biomass production by native species and are therefore excellent candidates for marginal land utilization. These two plant species comply with most of the requirements for energy plants, such as perennial character, huge amount of yearly harvested above-ground biomass, low need for pesticides and fertilisers, sequestration of nutrients to the underground parts before harvesting, adaptability to different conditions and tolerance to drought and frost. However, a significant disadvantage of giant reed is the high moisture content during harvesting (about 50\%) and the high ash content (3.5-5.5\%) (Ceotto \& Candilo 2010).

Species from the genus Miscanthus belong to perennial rhizomatous grasses. Within the genus, only one clone, Miscanthus $\times$ giganteus Greef et Deuter, is considered to be the most valuable for biomass production, and is grown commercially (Xue et al. 2015). M. $\times$ giganteus is the natural triploid infertile hybrid of diploid M. sinensis and tetraploid M. sacchariflorus (Greef \& Deuter 1993; Hodkinson et al. 2002), which was sampled in 1935 and introduced to Europe from Japan by Danish botanist A. Olson (Greef et al. 1997). Miscanthus belongs to C4 plants with high photosynthetic and water use efficiency (Atkinson 2009). It is considered an attractive and

Mgr. Marcela Gubišová, PhD. ( ${ }^{*}$ Corresponding author), Ing. Jozef Gubiš, PhD., Ing. Alžbeta Žofajová, PhD., National Agricultural and Food Centre - Research Institute of Plant Production, Bratislavská cesta 122, 92168 Piešt'any, Slovak Republic. E-mail: gubisova@vurv.sk 
environmentally friendly bioenergy plant with high production of ligno-cellulose biomass, which usually reaches annual yields ranging from 15 to 40 tons of dry matter per hectare (Clifton-Brown et al. 2001b).

A. donax L. is also a perennial rhizomatous grass originated from Asia. Plants are very adaptable to different conditions; they grow in tropical to warm-temperate regions, also on contaminated or salinized soils (Ceotto \& Candilo 2010). Plants similar to bamboo can grow up to $10 \mathrm{~m}$ in height, and due to its vigorous growth, the species is considered invasive (Pilu et al. 2013). Despite the C3 character of photosynthesis, the biomass yield can reach up to 78 tons per hectare annually, and due to hollow canes, it is easily processed into chips (Bass et al. 2014). Despite its invasiveness, in July 2013, the U.S. Environmental Protection Agency stated that giant reed yields three times as much ethanol per acre as maize, and qualified this plant as a cellulosic renewable fuel [http://www.newenergyfarms. com/crops/arundo-donax/]. Giant reed is known as a multipurpose plant that is used in paper and pulp industry, as a building material, for making musical instruments, fishing rods, walking sticks and stakes for plants (Pilu et al. 2012). It is also used in Ayurvedic medicine, as an ornamental plant and for phytoremediation of contaminated areas (Alshaal et al. 2014).

Both species do not produce viable seeds and can be multiplied by the vegetative methods only. On the other hand, the absence of seed production minimizes the risk of potential invasiveness. Even though these grasses belong to rhizomatous plants, the rhizome (Figure 1a) propagation method in giant reed is expensive and impractical (Ceotto \& Candilo 2010). Therefore, considering traditional methods, propagation by shoot cuttings offers greater potential. Although, for $M . \times$ giganteus, traditional propagation by rhizome segments (Figure 1b) is still predominant (Boersma \& Heaton 2014a), high demand for propagules needs simpler and more effective
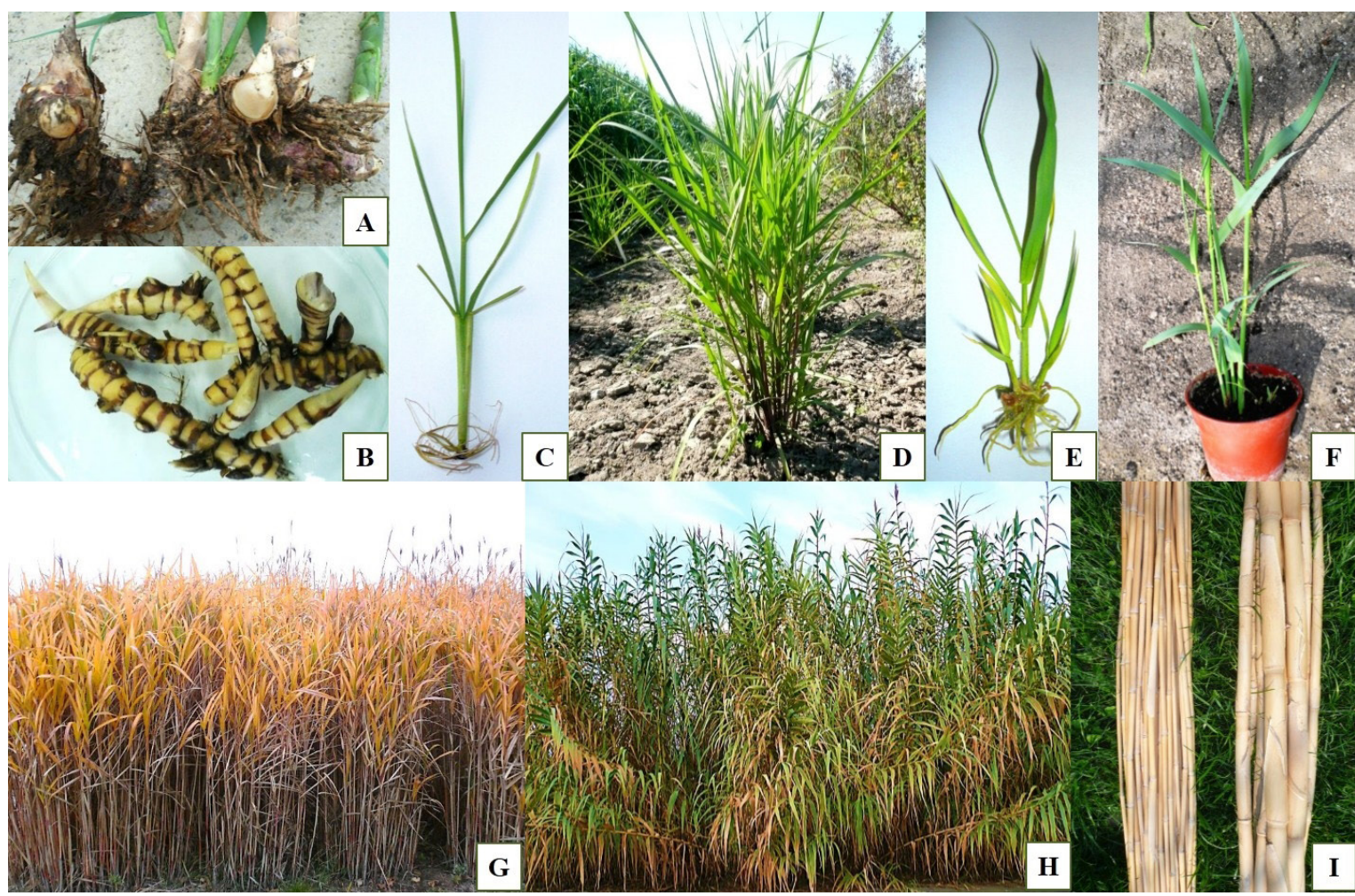

Figure 1. Propagation and biomass production of Arundo donax and Miscanthus $\times$ giganteus: A) rhizomes of $A$. donax, B) rhizomes of $M . \times$ giganteus, C) in vitro-multiplied plantlet and D) acclimatized plant of $M . \times$ giganteus after the transplantation into the field, E) in vitro-multiplied plantlet and F) acclimatized plant of $A$. donax, G) plants of $M . \times$ giganteus and H) A. donax at the end of October, I) dried biomass of M. $\times$ giganteus (left) and A. donax 
propagation systems (Atkinson 2009). Mann et al. (2013) compared ramet growth from whole shoots or shoot fragments of giant reed and miscanthus grass in California and found higher biomass production by whole shoots in both species. While axillary buds of miscanthus grass regenerated immediately after shoot cutting in spring and summer only, giant reed shoots regenerated throughout the year. Regeneration of miscanthus grass was lower (25-32\%) compared to giant reed (49-74\%), which propagates more readily from stem segments.

In vitro techniques (tissue cultures) offer an alternative tool for plant multiplication and have been commercially used for many plant species. It enables rapid multiplication of plants by direct shoot multiplication omitting the callus phase; indirectly through induction of callus followed by whole plant regeneration; or by a combination of both procedures. Moreover, tissue cultures also enable the production of pathogen-free plants and storage of plant material for a long time in controlled aseptic conditions. The important advantage of this method is the possibility of multiplying plants throughout the year and using in vitro breeding methods. In vitro techniques for the multiplication of $A$. donax (Cavallaro et al. 2011; Herrera-Alamillo \& Robert 2012; Antal et al. 2014; Gubišová et al. 2016) and M. × giganteus (Holme \& Petersen 1996; Lewandowski 1997; Glowacka et al. 2010; Gubišová et al. 2013) have already been described. In praxis, these plants are often called as "meristem plants". While the comparison of such plants with those propagated by traditional methods has been done for Miscanthus (Lewandowski 1998; Clifton-Brown et al. 2007), until now there was no data available for A. donax.

The aim of our experiments was to compare growth parameters and biomass production of plants multiplied by in vitro techniques and classical vegetative methods in two species of gigantic grasses - A. donax and $M$. $\times$ giganteus.

\section{MATERIAL AND METHODS}

\section{Plant material}

Two species of gigantic grasses were used in our experiments: $M$. $\times$ giganteus Greef et Deu (miscanthus grass) and A. donax L. (giant reed).
Mother plantation for experiments was established from rhizomes in both cases. Rhizomes of miscanthus grass were kindly provided by Mr. L. Sovák (SWHG Ltd., Valašské Meziřričí, Czech Republic).

\section{Characterization of the experimental site}

Field experiments were established in the locality of Piešt’any (west part of Slovakia) at an altitude of $163 \mathrm{~m}$ and a continental character of climate with long-time average annual precipitation of $608 \mathrm{~mm}$ and temperature of $9.2^{\circ} \mathrm{C}$. Soil type was Luvi-Haplic Chernozem; the locality belongs to a maize production type. The actual data of average monthly temperature and total monthly rainfall in the growing seasons 2013-2015 is given in Figure 2.

Plant multiplication methods and field establishment

Plants of $M . \times$ giganteus were multiplied in vitro via callus culture induced from immature inflorescences. Immature inflorescences were taken from 1-year-old mother plants. After regeneration from calli, the shoots were multiplied by in vitro tillering, elongated and rooted in the culture, and then transplanted to the soil (Figure 1c, d). The method is discussed in detail by Gubišová et al. (2013). Plantlets were acclimatized to ex vitro conditions and 10 weeks later, in June 2011, they were transplanted into the field. Control plants of miscanthus grass were established from rhizomes planted in the month of May of the same year.

Plants of $A$. donax were multiplied by in vitro tillering. The culture was established from stem segments with axillary bud of 1-year-old mother plants. Shoots regenerated from buds were multiplied and rooted in vitro, and then transplanted into the soil and acclimatized to ex vitro conditions (Figure 1e, f). The method is discussed in detail by Gubišová et al. (2016). Plants were transplanted into the field in June 2012. Control plants of giant reed were prepared from stem cuttings taken from mother plants in October 2011. Stem segments were cultivated in the sand, and regenerated and rooted shoots were transplanted into the garden substrate. During the winter 2011/2012, plants were cultivated under greenhouse conditions and transplanted into the field in the month of May 2012.

In the field, plantlets or rhizomes were planted at a spacing of $1 \times 1 \mathrm{~m}$. Plants were cultivated without 
irrigation and fertilisers. Plants growing along the edge of the plots were excluded from evaluation.

\section{Data measurement and evaluation}

Biomass production (Figure 1g, h, i) and growth parameters of plants cultivated in growing seasons of years 2013, 2014 and 2015 were evaluated during harvest in the month of March 2014, 2015 and 2016, respectively. The plants were evaluated for: the number of shoots per plant; thickness of the shoots (diameter [mm], measured at the base of the shoot); plant height $[\mathrm{cm}]$; biomass moisture [\%], measured by $(($ fresh weight - dry weight $) /$ fresh weight $) \times 100$; and yield of dry biomass per plant $(100 \%$ dry matter mass; content of dry matter mass was measured from three samples of each variant). Shoot diameter was the average shoot diameter (calculated from five randomly measured shoots per plant) in the case of miscanthus grass, or diameter of the thickest shoot in the case of giant reed. Twenty plants were evaluated for each parameter in both species. Experimental data were analysed by the analysis of variance (ANOVA) and means were then separated by $L S D$ test (the least significant difference) at $\alpha=0.05$ using the statistical software STATGRAFICS Centurion XVI.II (Statpoint Technologies, Inc., Virginia, USA).

\section{RESULTS AND DISCUSSION}

Growth parameters and the yield of dry biomass of $M . \times$ giganteus were measured in the third
(2013), fourth (2014) and fifth (2015) year of cultivation when these parameters are supposed to be already stabilized (Clifton-Brown et al. 2001a; Christian et al. 2008), although Polish experiments showed yield stabilization only after the third growing season (Jezowski et al. 2011). No statistically significant differences were observed between the two propagation methods (e.g. rhizomes versus in vitro-multiplied plantlets) for the number of shoots, plant height and the yield of above-ground biomass harvested in early spring. Statistically significant differences were observed only for shoot diameter, which was higher for rhizome-derived plants (Figure 3, Table 1). Lewandowski (1998) also mentioned that in vitro-multiplied plants showed smaller shoot diameter. Similar to our results, she also observed a higher number of shoots for in vitro-multiplied plants and no differences in shoot height. In our experiments, the yield of above-ground biomass was slightly higher for in vitro-multiplied plants in 2013 and 2014 (Figure 3). Lewandowski (1998) observed higher biomass production for in vitro-multiplied plants at one locality in Germany, but no differences at the other one. Clifton-Brown et al. (2007) found no differences in the biomass yield between rhizome-developed and in vitro-multiplied plants during a 16-year experiment in Southern Ireland.

Differences among years were statistically significant, except for the number of shoots. Higher rainfall in the year 2014 (124.6 mm for June and July together when the growth of plants is the most abundant, and $526.2 \mathrm{~mm}$ for the whole growing period) positively affected shoot height despite the low-

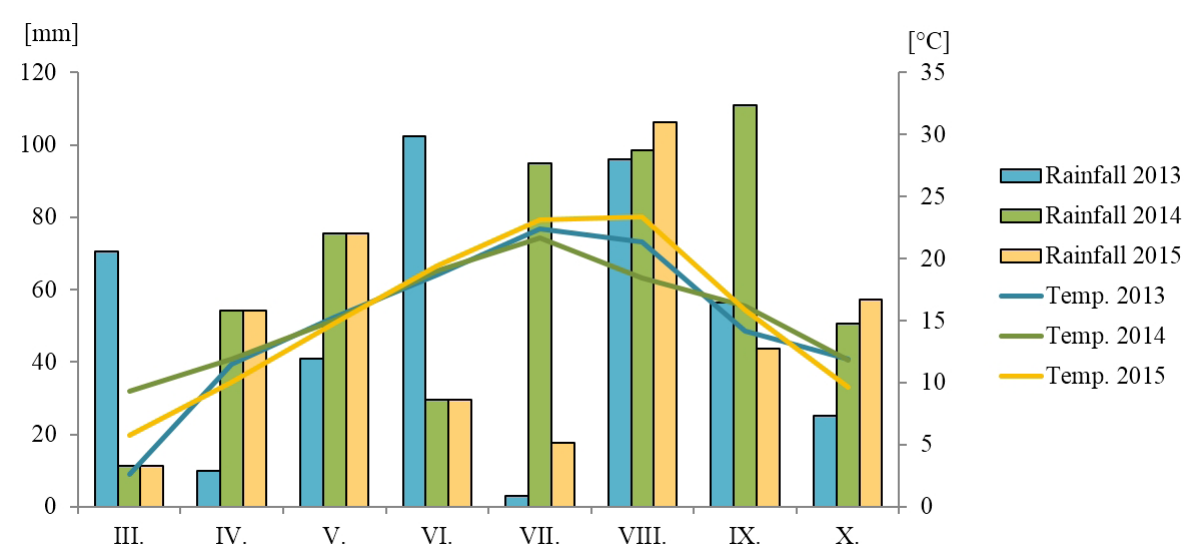

Figure 2. The average monthly temperature and total monthly rainfall during the growing seasons in the years 2013-2015 
est temperatures during this year, mainly in July and August, while in the dry growing season of the year 2015 (47.1 mm for June and July together, $272.6 \mathrm{~mm}$ for the whole growing period) (Figure 2), significantly shorter and thicker shoots were observed. Moisture content in harvested biomass was about $16 \%$ in March 2016 and 2014, and 28\% in March 2015. Such differences may have been caused by higher rainfall in the season of 2014 or different weather conditions during the winter before harvest. Despite different weather conditions in the monitored growing seasons, the yield of above-ground biomass gradually decreased from the year 2013 to 2015 (Figure 3, Table 1).

Lower winter freeze survival was mentioned for in vitro-multiplied plants (Lewandowski 1998). Plants are considered to be most susceptible to winter
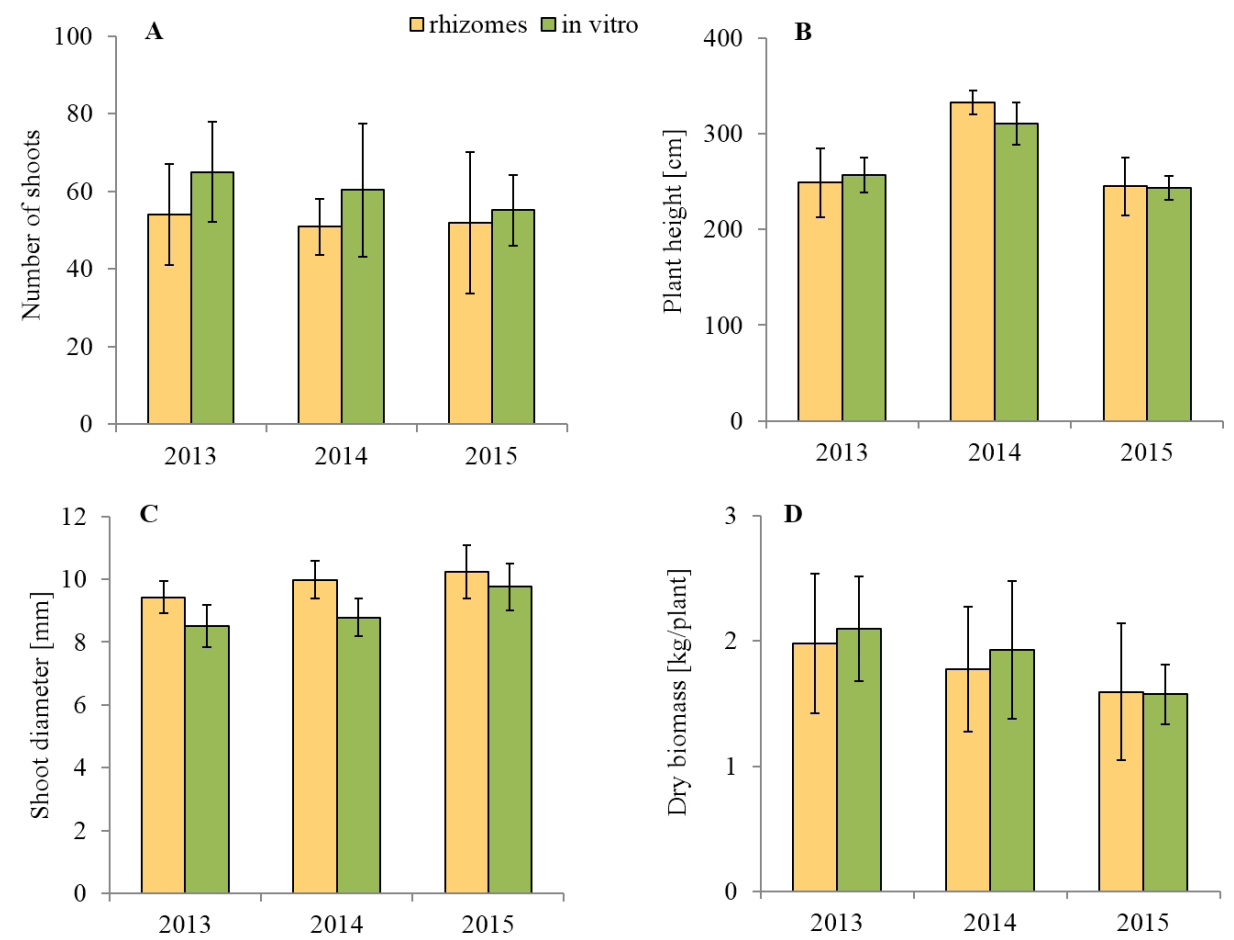

Figure 3. Miscanthus $\times$ giganteus. Growth parameters and biomass production during the third, fourth and fifth year of cultivation: A) the number of shoots per plant; B) plant height; C) diameter of shoots; D) production of dry biomass, calculated as $\mathrm{kg} / \mathrm{plant}$; average value \pm standard deviation

$\mathrm{T}$ a

Miscanthus giganteus - statistical evaluation of measured parameters

\begin{tabular}{|l|c|c|c|}
\hline \multirow{2}{*}{ Parameter } & Propagation method & \multicolumn{2}{|c|}{ Year } \\
\cline { 2 - 4 } & $P$-value & $P$-value & $\begin{array}{c}\text { Statistical differences by } L S D \\
(2013 / 2014 / 2015)\end{array}$ \\
\hline No. of shoots & 0.0518 & 0.4807 & $\mathrm{a} / \mathrm{a} / \mathrm{a}$ \\
Plant height & 0.4176 & $\mathbf{0 . 0 0 0 0}$ & $\mathrm{a} / \mathrm{b} / \mathrm{a}$ \\
Shoot diameter & $\mathbf{0 . 0 0 0 0}$ & $\mathbf{0 . 0 0 0 3}$ & $\mathrm{a} / \mathrm{a} / \mathrm{b}$ \\
Dry biomass & 0.5180 & $\mathbf{0 . 0 1 9 8}$ & $\mathrm{b} / \mathrm{ab} / \mathrm{a}$ \\
\hline
\end{tabular}

$P$-value by analysis of variance (bold font indicates statistically significant difference at $\alpha=0.05$ ); $L S D$ (the least significant difference) test was used as a multiple range test for evaluated years (different letters indicate statistically significant difference at $\alpha=0.05$ ) 
frost during the first winter after field establishment (Clifton-Brown \& Lewandowski 2000; Jezowski et al. 2011). In our experiment, in vitro-multiplied plants of $M . \times$ giganteus were transplanted into the field in the year 2011. The winter of 2011/2012 was characterised by very low temperature here. During the first two weeks of February 2012, the minimal temperature was measured from $-10.3^{\circ} \mathrm{C}$ to $-16.0^{\circ} \mathrm{C}$ and the soil remained frozen throughout the day (the minimal soil temperature in these days was from -1.9 to $-4.6^{\circ} \mathrm{C}$ ), which has not been a common occurrence in this locality during the past few years. Despite this, we did not observe any plant losses during this winter (2011/2012), as well as no establishment losses in the first year. There were only some losses $(4.9 \%)$ during the phase of acclimatization to ex vitro conditions. Plant survival may have also been affected by the fact that plants transplanted to the field were strong and vital, as they were appropriately pre-cultivated in pots with $0.25 \mathrm{dm}^{3}$ of the garden substrate for a period of ten weeks. Based on worldwide experiences, Clifton-Brown and Lewandowski (2000) suggested that larger plants can survive better than smaller ones. Boersma and Heaton (2014b) compared the survival of rhizome and stem-propagated plants of miscanthus grass in the field and did not find statistically significant differences between these two groups. They observed much higher mortality in the phase of the field establishment compared to winter losses $(23.7 \%$ vs $1.2 \%)$. The interesting fact is that they also observed lower number of shoots per plant and higher basal circumference for rhizomepropagated plants. Authors explained that the higher number of shoots in stem-propagated plants may be due to the inherent characteristics of aerial organs, including native hormone levels. These observations were the same for the comparison of rhizome versus in vitro propagated plants in our experiment and the experiments of Lewandowski (1998).

A completely different situation was observed for plants of $A$. donax. Under in vitro conditions, plants were regenerated directly from axillary buds and then multiplied. Control plants were also regenerated from axillary buds but were then stored under greenhouse conditions for the whole winter. It caused that plants from stem segments had been stronger with probably more enlarged underground
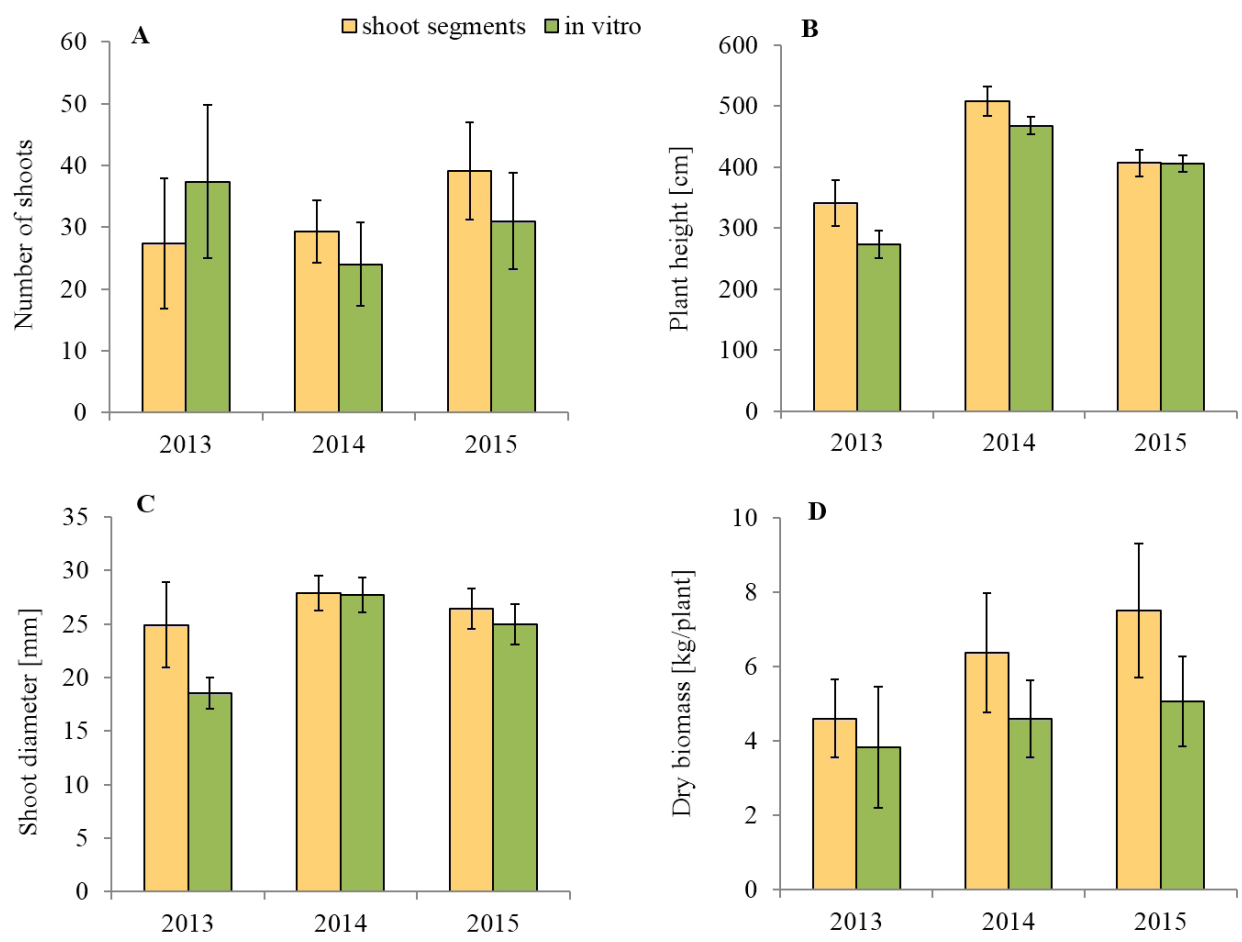

Figure 4. Arundo donax. Growth parameters and biomass production during the second, third and fourth year of cultivation: A) the number of shoots per plant; B) plant height; C) diameter of the thickest shoot; D) the production of dry biomass, calculated as $\mathrm{kg} / \mathrm{plant}$; average value \pm standard deviation 
part compared to plants multiplied in vitro. It could redound to the advantage of these plants in the field conditions and may have been the important one, but not the only, reason for higher biomass production. It is important to mention that there were no losses (as well for $M . \times$ giganteus) during field establishment or in winter in both groups of plantlets, and losses during acclimatization to ex vitro conditions were only $4.4 \%$.

In the first year of evaluation of giant reed, the plants were only in the second year of cultivation, contrary to miscanthus grass. Different results were observed in the number of shoots compared to next years (Figure 4). Statistical evaluation of the complete results is shown in Table 2, and with the exception of the number of shoots, significant differences between propagation methods were observed for other measured parameters. When the first year, 2013, was excluded from the evaluation, significant differences between propagation methods were measured also for the number of shoots $(P=0.0065)$. In the first year, the number of shoots was higher for in vitro-multiplied plants, but from the second year onwards, it turned reverse (Figure 4). The higher number of shoots in the first year may have been caused by the effect of plant growth regulators used for the induction of in vitro tillering, which persist in plant tissues and confer a residual hormonal response (Boersma \& Heaton 2014a), or it can be explained by the greater development of meristems forming buds at the base of the in vitro-multiplied plantlets.

If only the second and third years of measurement were compared, the difference in shoot diameter between stem-propagated and in vitro-propagated plants were not statistically significant $(P=0.1569)$. Nevertheless, there was visually detectable difference between the circumferences of the sheaf of cut shoots on the basal side. Parameter stem diameter may have been slightly distorted here because the diameter of the thickest shoot only was measured in the case of giant reed plants. It was measured that way because the diameter of the shoot of giant reed is, in contrast to miscanthus grass, variable (varies from 0.8 to $30 \mathrm{~mm}$ ) and it would be too laborious to determine the exact average value. Therefore, the circumference of the shoot sheaf was measured in the third year, and it was $60.17 \pm 6.36 \mathrm{~cm}$ for stem-propagated plants and $50.67 \pm 9.27 \mathrm{~cm}$ for in vitro-multiplied plants. It is clear from these measurements that the stem-propagated plants had a higher proportion of thicker shoots, although the diameter of the thickest shoot was not different.

Generally, the stem-propagated plants of giant reed showed better results in all measured parameters than the in vitro-multiplied plants (Figure 4). Differences among years were statistically significant for all parameters, also in the case when only the years 2014 and 2015 were compared. Shoot height and diameter were highest in the year 2014 (Figure 4). Contrary to $M . \times$ giganteus, in the case of A. donax, the yield of above-ground biomass gradually increased, and the highest yield was measured in the year 2015 despite deficient rainfall. Probably, the age of plants or higher temperatures in that year may have been the stronger factor affecting the growth of above-ground biomass. It is noteworthy also that plants growing on the edge of the plot gave much more biomass than other plants, and due to this

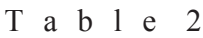

Arundo donax - statistical evaluation of measured parameters

\begin{tabular}{|l|c|c|c|}
\hline \multirow{2}{*}{ Parameter } & Propagation method & \multicolumn{2}{|c|}{ Year } \\
\cline { 2 - 4 } & $P$-value & $P$-value & $\begin{array}{c}\text { Statistical differences by } L S D \\
(2013 / 2014 / 2015)\end{array}$ \\
\hline No. of shoots & 0.6607 & $\mathbf{0 . 0 1 2 0}$ & $\mathrm{ab} / \mathrm{a} / \mathrm{b}$ \\
Plant height & $\mathbf{0 . 0 0 0 0}$ & $\mathbf{0 . 0 0 0 0}$ & $\mathrm{a} / \mathrm{c} / \mathrm{b}$ \\
Shoot diameter & $\mathbf{0 . 0 0 0 2}$ & $\mathbf{0 . 0 0 0 3}$ & $\mathrm{a} / \mathrm{c} / \mathrm{b}$ \\
Dry biomass & $\mathbf{0 . 0 0 0 7}$ & $\mathbf{0 . 0 0 5 3}$ & $\mathrm{a} / \mathrm{ab} / \mathrm{b}$ \\
\hline
\end{tabular}

$P$-value by analysis of variance (bold font indicates statistically significant difference at $\alpha=0.05$ ); LSD (the least significant difference) test was used as a multiple range test for evaluated years (different letters indicate statistically significant difference at $\alpha=0.05$ ) 
fact, these plants were excluded from evaluation. The comparison was accomplished in the spring of 2015 and biomass yields were $4.59 \mathrm{~kg} /$ plant versus $8.53 \mathrm{~kg} /$ plant (plants on the edge of the plot). The situation was very similar in the case of $M$. $\times$ giganteus also.

An interesting fact is that, in our field conditions, the differences in biomass yield of giant reed and miscanthus grass were much higher in comparison with the long-term experiment of Angelini et al. (2009) in Italy, where the average yield of $A$. donax was 37.7 tons and $M . \times$ giganteus was 28.7 tons of dry matter per hectare.

Moisture content in harvested biomass was about $43 \%$ in March 2014 and 2015 but only 31\% in March 2016. In contrast to M. × giganteus, where the atypically high moisture content in the harvested biomass was measured after the "wet" growing season of 2014, in A. donax, the typical moisture content was measured in this year, but unusually low moisture content was measured after the "dry" season of 2015.

\section{CONCLUSIONS}

We can conclude that the propagation method may affect morphological and yield parameters of miscanthus and giant reed plants. One of the alternative methods of vegetative propagation is in vitro multiplication via tissue cultures. Apart from the cost of plant propagation, in vitro multiplication of vegetatively propagated gigantic grasses is considered an interesting tool for rapid plant multiplication, particularly when a new clone or cultivar has to be propagated in a very short time. Even though the growth of plants in the field conditions may be affected by the method of propagation, strong influence of plant size and vitality independent of propagation method and growth conditions, including date of planting, soil quality and weather conditions, should be considered. In our experiment, the effect of year connected with different weather conditions was stronger than the effect of the method of plant propagation in the case of miscanthus grass. In the case of giant reed, significant effect of both factors was observed. In our study, we confirmed the results of previous studies on $M . \times$ giganteus and ob- tained new information concerning the differences in growth parameters of $A$. donax plants multiplied by conventional vegetative propagation and in vitro method.

Acknowledgements. This work was funded by the Ministry of Agriculture and Rural Development of Slovak Republic in the frame of R\&D projects: "The development and innovation of primary plant production for securing food safety, sustainable agriculture and decreasing of environmental damage" and "Innovation of growing systems for sustainability and quality of primary plant production considering climate changes, protection of the environment and countryside development".

\section{REFERENCES}

ALSHAAL, T. - ELHAWAT, N. - DOMOKOSSZABOLCSY, É. - KÁTAI, J. - MÁRTON, L. - CZAKO, M. - EL-RAMADY, H. - FÁRI, M.G. 2014. Giant reed (Arundo donax L.): A green technology for clean environment. In ANSARI, A.A. - GILL, S.S. - GILL, R. - LANZA, G.R. - NEWMAN, L. (Eds) Phytoremediation: Management of Environmental Contaminants, Springer International Publishing, Switzerland, pp. 3-20. DOI:10.1007/ 978-3-319-10395-2_1

ANGELINI, L.G. - CECCARINI, L. - NASSI O DI NASSO, N. - BONARI, E. 2009. Comparison of Arundo donax L. and Miscanthus $x$ giganteus in a long-term field experiment in Central Italy: Analysis of productive characteristics and energy balance. In Biomass and Bioenergy, vol. 33, no. 4, pp. 635-643. DOI: 10.1016/j.biombioe.2008.10.005

ANTAL, G. - KURUCZ, E. - FÁRI, M.G. - POPP, J. 2014. Tissue culture and agamic propagation of winter-frost tolerant 'Longicaulis' Arundo donax L. In Environmental Engineering and Management Journal, vol. 13, no. 11, pp. 2709-2715.

ATKINSON, C.J. 2009. Establishing perennial grass energy crops in the UK: A review of current propagation options for Miscanthus. In Biomass and Bioenergy, vol. 33 , no. 4 , pp. 752-759. DOI: 10.1016/j.biombioe.2009.01.005

BASS, R. - GARCIA-PEREZ, M. - HORNECK, D. LEWIS, M. - PAN, B. - PETERS, T. - STEVENS, B. - WYSOCKI, D. 2014. Carbon implications of converting a coal-fired power plant to combustion of torrefied Arundo donax. In Applied Bioenergy, vol. 1, no. 1 , pp. 30-43. DOI: 10.2478 /apbi-2014-0002

BOERSMA, N.N. - HEATON, E.A. 2014a. Propagation method affects Miscanthus $\times$ giganteus developmental morphology. In Industrial Crops and Products, vol. 57, pp. 59-68. DOI:10.1016/j.indcrop.2014.01.059

BOERSMA, N.N. - HEATON, E.A. 2014b. Does prop- 
agation method affect yield and survival? The potential of Miscanthus $\times$ giganteus in Iowa, USA. In Industrial Crops and Products, vol. 57, pp. 43-51. DOI:10.1016/j.indcrop.2014.01.058

CAVAllaro, V. - TRINGALI, S. - PATANE, C. 2011. Large-scale in vitro propagation of giant reed (Arundo donax L.), a promising biomass species. In The Journal of Horticultural Science and Biotechnology, vol. 86, no. 5, pp. 452-456. DOI:10.1080/14620316. 2011.11512787

CEOTTO, E. - CANDilo, M.D. 2010. Shoot cuttings propagation of giant reed (Arundo donax L.) in water and moist soil: The path forward? In Biomass and Bioenergy, vol. 34, no. 11, pp. 1614-1623. DOI:10.1016/j.biombioe.2010.06.002

CHRISTIAN, D.G. - RICHE, A.B. - YATES, N.E. 2008. Growth, yield and mineral content of Miscanthus $\times$ giganteus grown as a biofuel for 14 successive harvests. In Industrial Crops and Products, vol. 28, pp. 320-327.

CLIFTON-BROWN, J.C. - BREUER, J. - JONES, M.B. 2007. Carbon mitigation by the energycrop, Miscanthus. In Global Change Biology, vol. 13, no. 11, pp. 2296-2307. DOI: 10.1111/j.1365-2486.2007.01438.x

CLIFTON-BROWN, J.C. - LEWANDOWSKI, I. 2000. Overwintering problems of newly established Miscanthus plantations can be overcome by identifying genotypes with improved rhizome cold tolerance. In New Phytologist, vol. 148, no. 2, pp. 287-294.

CLIFTON-BROWN, J.C. - LEWANDOWSKI, I. - ANDERSON, B. - BASCH, G. - CHRISTIAN, D. KJELDSEN, J.B. - JØRGENSEN, U. - MORTENSEN, J. - RICHE, A. - SCHWARZ, K.U. - TAYEBI, K. TEIXEIRA, F. 2001 a. Performance of 15 Miscanthus genotypes at five sites in Europe. In Agronomy Journal, vol. 93, no. 5, pp. 1013-1019. DOI: 10.2134/ agronj2001.9351013x

CLIFTON-BROWN, J.C. - LONG, S.P. - JØRGENSEN, U. 2001b. Miscanthus productivity. In JONES, M.B. - WALSH, M. Miscanthus for Energy and Fibre. London, UK : James \& James Ltd. ISBN 1-902916-07-7, pp. 46-67.

GŁOWACKA, K. - JEŻOVSKI, S. - KACZMAREK, Z. 2010. The effects of genotype, inflorescence developmental stage and induction medium on callus induction and plant regeneration in two Miscanthus species. In Plant Cell Tissue and Organ Culture, vol. 102, no. 1, pp. 79-86. DOI: 10.1007/s11240-010-9708-6

GREEF, J.M. - DEUTER, M. 1993. Syntaxonomy of Miscanthus $\times$ giganteus GREEF et DEU. In Angewandte Botanik, vol. 67, no. 3-4, pp. 87-90.

GREEF, J.M. - DEUTER, M. - JUNG, C. - SCHONDELMAIER, J. 1997. Genetic diversity of European Miscanthus species revealed by AFLP fingerprinting. In Genetic Resources and Crop Evolution, vol. 44, no. 2, pp. 185-195. DOI: 10.1023/A:1008693214629

GUBIŠOVÁ, M. - ČIČKOVÁ, M. - KLČOVÁ, L. - GUBIS̆, J. 2016. In vitro tillering - An effective way to multiply high-biomass plant Arundo donax. In In- dustrial Crops and Products, vol. 81, pp. 123-128. DOI: $10.1016 / \mathrm{j}$.indcrop. 2015.11 .080

GUBIŠOVÁ, M. - GUBIŠ, J. - ŽOFAJOVÁ, A. - MIHÁLIK, D. - KRAIC, J. 2013. Enhanced in vitro propagation of Miscanthus x giganteus. In Industrial Crops and Products, vol. 41, pp. 279-282. DOI:10.1016/j. indcrop.2012.05.004

HERRERA-ALAMILLO, M.A. - ROBERT, M.L. 2012. Liquid in vitro culture for the propagation of Arundo donax. In LOYOLA-VARGAS, V.M. - OCHOA-ALEJO, N. (Eds) Plant Cell Culture Protocols: Methods in Molecular Biology 877. Humana Press, pp. 153-160.

HODKINSON, T.R. - CHASE, M.W. - RENVOIZE, S.A. 2002. Characterization of a genetic resource collection for Miscanthus (Saccharinae, Andropogoneae, Poaceae) using AFLP and ISSR PCR. In Annals of Botany, vol. 89, no. 5, pp. 627-636. DOI: 10.1093/ aob/mcf091

HOLME, I.H. - PETERSEN, K.K. 1996. Callus induction and plant regeneration from different explant types of Miscanthus x ogiformis Honda 'Giganteus'. In Plant Cell Tissue Organ Culture, vol. 45, no. 1, pp. 43-52. DOI: $10.1007 / \mathrm{BF} 00043427$

JEZOWSKI, S. - GLOWACKA, K. - KACZMAREK, Z. 2011. Variation on biomass yield and morphological traits of energy grasses from the genus Miscanthus during the first years of crop establishment. In Biomass and Bioenergy, vol. 35, no. 2, pp. 814-821. DOI: $10.1016 /$ j.biombioe.2010.11.013

LEWANDOWSKI, I. 1997. Micropropagation of Miscanthus $\times$ giganteus. In BAJAJ, Y.P.S. (Ed) Biotechnology in Agriculture and Forestry, vol. 39. HighTech and Micropropagation V. Springer Verlag, Berlin, Heidelberg, pp. 239-255.

LEWANDOWSKI, I. 1998. Propagation method as an important factor in the growth and development of Miscanthus $\times$ giganteus. In Industrial Crops and Products, vol. 8, pp. 229-245.

MANN, J.J. - KYSER, G.B. - BARNEY, J.N. - DITOMASO, J.M. 2013. Assessment of aboveground and belowground vegetative fragments as propagules in the bioenergy crops Arundo donax and Miscanthus $x$ giganteus. In BioEnergy Research, vol. 6, no. 2, pp. 688-698. DOI: 10.1007/s12155-012-9286-Z

PILU, R. - BUCCI, A. - BADONE, F.C. - LANDONI, M. 2012. Giant reed (Arundo donax L.): A weed plant or a promising energy crop? In African Journal of Biotechnology, vol. 11, no. 38, pp. 9163-9174. DOI: 10.5897/AJB 11.4182

PILU, R. - MANCA, A. - LANDONI, M. 2013. Arundo donax as an energy crop: pros and cons of the utilization of this perennial plant. In Maydica, vol. 58, pp. 54-59.

XUE, S. - KALININA, O. - LEWANDOWSKI, I. 2015. Present and future options for Miscanthus propagation and establishment. In Renewable and Sustainable Energy Reviews, vol. 49, pp. 1233-1246. DOI: $10.1016 /$ j.rser.2015.04.168

Received: May 20, 2016 